\title{
Differentiating past events on a cone influenced by debris-flow and snow avalanche activity - a dendrogeomorphological approach
}

\author{
Markus Stoffel,* Michelle Bollschweiler and Gion-Reto Hassler \\ Laboratory of Dendrogeomorphology, Department of Geosciences, Geography, University of Fribourg, Switzerland
}

* Correspondence to:

Markus Stoffel, Laboratory

of Dendrogeomorphology,

Department of Geosciences,

Geography, University of Fribourg,

chemin du Musée 4, 1700

Fribourg Switzerland.

E-mail: markus.stoffel@unifr.ch

\begin{abstract}
Dendrogeomorphology was used to investigate past events on a cone affected by both debris flows and snow avalanches. We report on results of 520 cores from 251 injured Larix decidua Mill. and Picea abies (L.) Karst. trees sampled on the Birchbach cone (Swiss Alps). Detailed analysis of tree-ring sequences allowed dating of 561 growth disturbances in individual trees for a $252 \mathrm{yr}$ period, extending from 1750 to 2002, which could be attributed to 30 different event years. We then localized the position of rows of traumatic resin ducts (TRDs) within the tree ring so as to assess the intra-seasonal position of damage. In agreement with data on the local growth period, TRDs located at the beginning of the new growth ring were considered the result of avalanche impacts that occurred during the dormant season or in earliest earlywood between late October and early May. In contrast, TRD found in late earlywood or within latewood were considered the result of periglacial debris-flow activity, as these layers of the tree ring are locally formed between July and early October.

For nine out of the 30 reconstructed event years, the intra-seasonal timing of TRDs indicated that reactions must be the result of past snow avalanche activity. In 19 other event years, TRDs showed that damage has been caused between July and early October and, thus, through debris flows in the Birchbach torrent. Finally, the spatial patterns of trees showing reactions as a result of particular events were assessed so as to approximate the extent of past debris flows and snow avalanches.
\end{abstract}

Keywords: debris flow; snow avalanche; dendrogeomorphology; frequency; Swiss Alps

\section{Introduction}

Debris-flow and snow avalanche activity can frequently be observed in mountain regions, where their repeated occurrence may result in characteristic landforms, such as cone-shaped debris accumulations at the mouth of gullies or torrent valleys. Typical morphologies of debris-flow or snow avalanche landforms have repeatedly been described in the literature. As for the processes and forms related to debris flows, past investigations primarily focused on, e.g., their flow behaviour and rheology (Costa, 1984, 1988; Johnson and Rodine, 1984; Takahashi, 1991; Rickenmann, 1999; Johnson, 2003; Bollschweiler et al., 2005) or on triggering factors (Caine, 1980; Bovis and Jakob, 1999; Huggel et al., 2002; Cannon et al., 2003; Stoffel et al., 2003). In a similar way, the magnitude and frequency of debris flows have repeatedly been reconstructed or the moment of past activity assessed by means of field investigations (e.g. Hungr et al., 1984; Zimmermann et al., 1997), lichenometry (e.g. Rapp and Nyberg, 1981; Innes, 1985; Jonasson et al., 1991; Helsen et al., 2002) or dendrogeomorphological analyses (e.g. Strunk, 1995, 1997; Baumann and Kaiser, 1999; May and Gresswell, 2004; Jakob et al., 2005; Stoffel et al., 2005a).

Research on characteristic forms, landscapes or the geomorphic activity of snow avalanches has commonly been based on the pioneering results obtained in Rapp's 'Kärkevagge' study (Rapp, 1960), which provided the first detailed 
descriptions and quantitative estimates of debris transport and erosion by snow avalanches. Since that study, the geomorphic work of snow avalanches, the morphology of runout zones or avalanche talus as well as debris transport by avalanches have been analysed and quantified in different mountainous regions all over the world (see, e.g., Gardner, 1970; Luckman, 1977, 1978; Hubert, 1982; Ward, 1985; Ackroyd, 1986; André, 1990; Bell et al., 1990; Smith and McClung, 1997; Jomelli, 1999). Similarly to debris flows, deposits from former events have been dated by radiocarbon (Smith et al., 1994), lichenometric (McCarroll, 1993; Matthews and McCarroll, 1994) and dendrogeomorphological analyses (Johnson et al., 1985; Butler et al., 1992; Patten and Knight, 1994; Rayback, 1998; Hebertson and Jenkins, 2003).

However - and even though Luckman (1992) pertinently emphasizes that debris-flow and snow avalanche processes regularly occupy common starting and runout zones - analyses so far have only exceptionally focused on both processes simultaneously. Moreover, the few studies addressing avalanche landscapes in general and the occurrence of both processes in particular have most frequently been realized above tree line or on non-forested slopes. Similarly, tree-ring analyses have, up to now, only been used to reconstruct past events in forest stands influenced either by debris-flow or snow avalanche activity, but not by both processes at the same time.

It is therefore the purpose of this study to simultaneously investigate and date past debris-flow and snow avalanche activity on a forested cone in the Swiss Alps. We report on results obtained from dendrogeomorphological analysis covering the last 252 years. The present paper primarily provides an illustration of how growth disturbances caused by debris-flow events can be differentiated from signs associated with snow avalanche activity in heavily disturbed Larix decidua Mill. and Picea abies (L.) Karst. trees. Thereafter, we assess the approximate area affected as well as the origin of past debris-flow and snow avalanche events on the cone using tree-ring records in conjunction with the results from geomorphic mapping.

\section{Study Area}

The area investigated within the present study is the Birchbach cone, located southeast of the village of Blatten (Lötschental valley, Swiss Alps, $46^{\circ} 25^{\prime} \mathrm{N} / 7^{\circ} 49^{\prime} \mathrm{E}$; Figure 1). The catchment area of the Birchbach torrent covers $2.54 \mathrm{~km}^{2}$ and the length of the primary channel totals $2.65 \mathrm{~km}$. The cone itself is illustrated in Figure 2 and extends from approximately 1500 to $1660 \mathrm{~m}$ a.s.l. It has a mean slope gradient of $17^{\circ}$, a cone area of $0.72 \mathrm{~km}^{2}$ and is covered with an open forest composed of European larch (Larix decidua Mill.) and a few Norway spruce trees (Picea abies (L.) Karst.). While the apex of the cone remains largely free of vegetation, pioneer bushes such as green alder (Alnus viridis (Chaix) DC.) colonize those areas of the site repeatedly affected by snow avalanches. Meteorological data for Ried (see Figure 1) indicate mean yearly precipitation totals of $1113 \mathrm{~mm}$ and a mean temperature of $4.8^{\circ} \mathrm{C}$. The growth period of Larix decidua and Picea abies lasts locally from early May to mid-October (Fischer, 1980).

Debris flow material commonly originates from the huge, unconsolidated morainic deposits located in the forefields of the hanging glacier northwest of the Bietschhorn summit (3934 m a.s.l., Figure 1). The material consists of paragneissic and granite basement rocks of the Aar massif (Labhart, 2004). The high elevation of the departure zone and the presence of contemporary permafrost indicated by a regionally calibrated GIS model (Imhof, 1996) restrict the release of debris flows to a few months in summer and early autumn. Evidence for past debris flows is available from oral history for the 16th century (Guntern, 1978).

Snow avalanches reaching the cone primarily pass through the 'Birchchinn' avalanche gully shown in Figure 2. It is, however, possible that exceptionally large (powder) snow avalanches passing the 'Nästchinn' or 'Blötza' tracks may cause damage to trees growing on the Birchbach cone as well. A large database on 286 destructive snow avalanche events since 1680 exists for the Lötschental valley and is illustrated in Table I. Records suggest that more than $70 \%$ of the snow avalanches occurred in December, January or February. The database also contains records for the 'Birchchinn', 'Nästchinn' and 'Blötza' tracks (Figure 2; Table I), indicating that avalanches would have been triggered exclusively between December and March (Bellwald, 2003). Wet-snow avalanches occurring within the growth period of Larix decidua and Picea abies have never been attested on the Birchbach cone. In contrast, destructive snow avalanche events in May or even early June are known to have repeatedly reached the valley floor southwest of the village of Wiler (Figure 1).

As a reaction to the debris-flow and snow avalanche activity, a large protection dam $(390 \mathrm{~m}$ in length, $12 \mathrm{~m}$ in height) was built on the slope in the early 1990s so as to protect the buildings located at the northeastern edge of the Birchbach cone. On the slope opposite the cone, a road gallery was constructed in 1993 in order to protect the main road connecting Blatten with Wiler from future 'Blötza' avalanches (Jossen, 1994; SLF, 2000; Figure 2). 


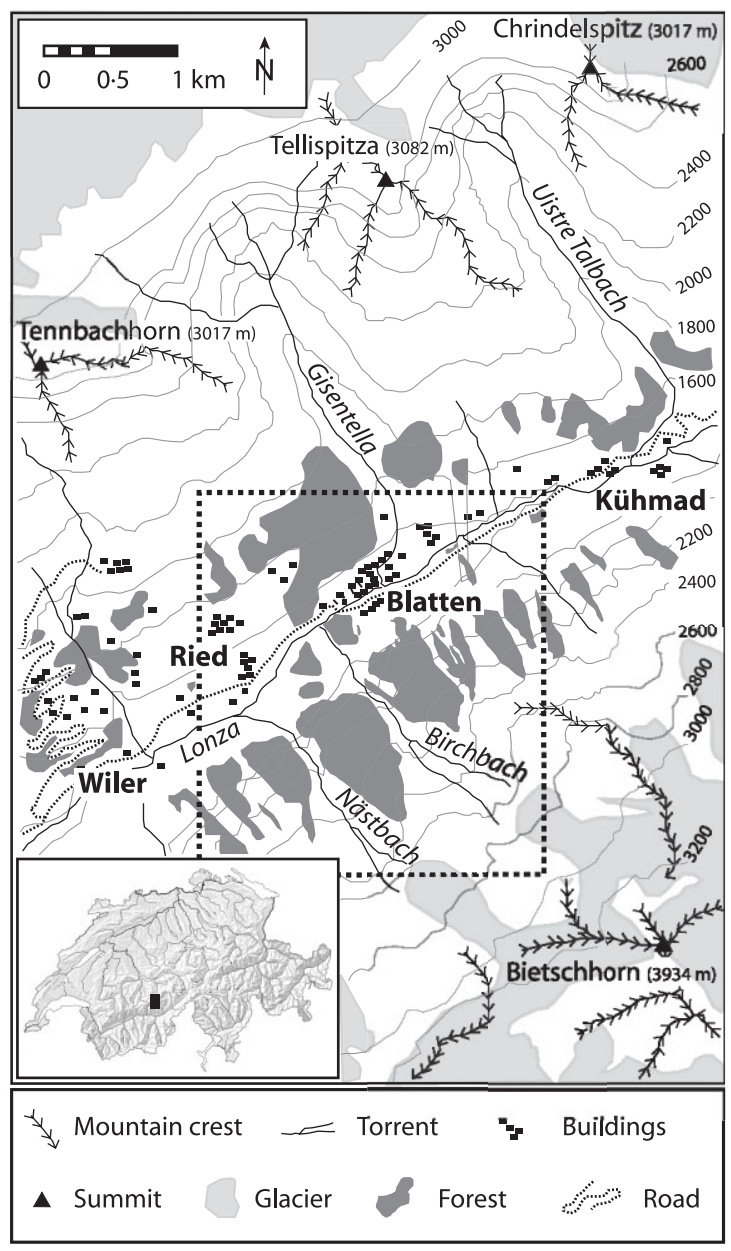

Figure I. Location of the study site Blatten as well as the meteorological station Ried within the central Lötschental valley (Valais, Switzerland). The dashed rectangle indicates the area illustrated in Figure 2.

Table I. Archival data on the timing of past snow avalanche activity (adapted from Bellwald, 2003)

\begin{tabular}{|c|c|c|c|c|}
\hline $\begin{array}{l}\text { Timing of avalanches } \\
\text { (archival data) }\end{array}$ & $\begin{array}{l}\text { Lötschental } \\
\text { (1680-2003) }\end{array}$ & $\begin{array}{l}\text { Birchchinn } \\
\text { (1808-2003) }\end{array}$ & $\begin{array}{l}\text { Nästchinn } \\
(1693-2003)\end{array}$ & $\begin{array}{c}\text { Blötza } \\
(1945-2003)\end{array}$ \\
\hline Not specified ('winter') & $21(7 \cdot 4 \%)$ & - & - & - \\
\hline September & I (0.3\%) & - & - & - \\
\hline October & $4(1.4 \%)$ & - & - & - \\
\hline November & $4(1 \cdot 4 \%)$ & - & - & - \\
\hline December & $47(16 \cdot 4 \%)$ & 2 & । & - \\
\hline January & 71 (24.8\%) & - & 1 & 2 \\
\hline February & $88(30 \cdot 8 \%)$ & I & । & 3 \\
\hline March & $26(9 \cdot 1 \%)$ & 1 & 2 & - \\
\hline April & $14(4.9 \%)$ & - & - & - \\
\hline May & $7(2 \cdot 4 \%)$ & - & - & - \\
\hline June & $3(1 \cdot 1 \%)$ & - & - & - \\
\hline TOTAL & 286 & 4 & 5 & 5 \\
\hline
\end{tabular}



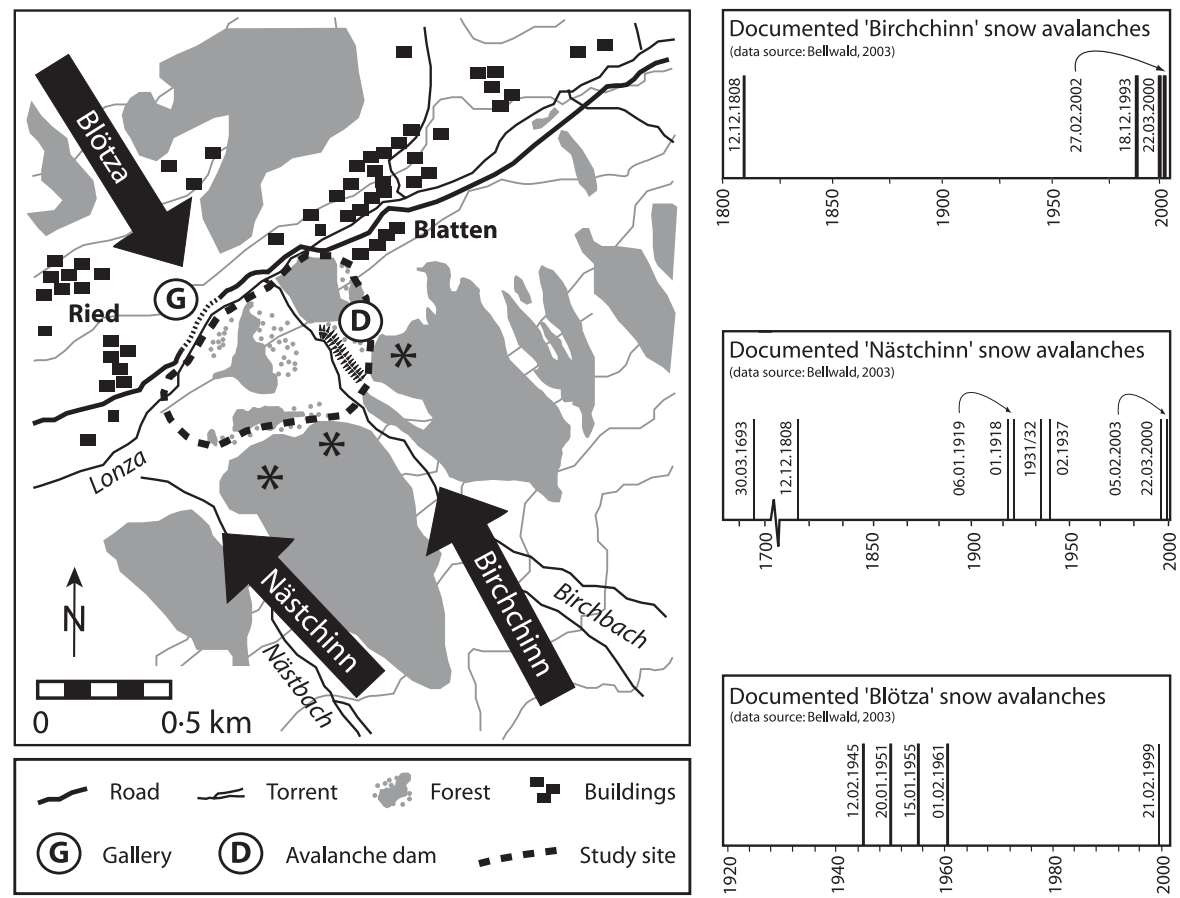

Figure 2. (Left) Avalanche tracks and debris-flow torrents that might influence the Birchbach cone. Note the large earth-fill dam (D) and the road gallery $(G)$ constructed in the early 1990s to protect the settlement of Blatten as well as the road connecting the village with Ried and the main valley. In the areas indicated with asterisks, undisturbed trees were sampled to build a local reference chronology. The dashed polygon gives the position of the area investigated. (Right) Archive data on past snow avalanche events in the 'Birchchinn', 'Nästchinn' and 'Blötza' tracks.

\section{Material and Methods}

\section{Geomorphic mapping and sampling of increment cores}

In a first step, geomorphic mapping of forms and deposits associated with past debris-flow and snow avalanche activity was realized in a scale of 1:1000 and the position of disturbed trees growing on the cone assessed. Thereafter, 520 increment cores were sampled from 251 Larix decidua and Picea abies trees that had obviously been disturbed by past debris flows and/or snow avalanches. Within this study, we preferably selected trees with scars, candelabra growth, loss of apex, as well as buried or tilted stems resulting from past events. Two cores per tree were then extracted with increment borers, one in the flow direction of past snow avalanches and debris flows and another on the opposite side of the trunk (max. length of cores $40 \mathrm{~cm}, \varnothing 6 \mathrm{~mm}$ ). To gather a maximum of information on the growth disturbances (GD) caused by past events, increment cores were preferably sampled at the height of the visible damage or within the segment of the stem tilted during past events.

Furthermore, additional data were gathered for each tree sampled. Information included (i) a determination of its 3D position within the deposits; (ii) sketches and position of visible defects in the tree morphology, such as scars, broken crowns or branches, candelabra growth or tilted stems; (iii) the position of cores sampled (i.e. upslope, downslope, other); (iv) tree diameter at breast height $(\mathrm{DBH})$ derived from circumference measurements and (v) data on neighbouring trees as well as micro-topography.

\section{Tree-ring analyses}

Samples were then prepared in the laboratory as described by Phipps (1985) and Krusic et al. (1987), before the cores were analysed visually and obvious growth anomalies noted on 'skeleton plots' (Schweingruber et al., 1990). Ringwidths of disturbed increment cores were measured using a digital LINTAB positioning table connected to a Leica microscope and TSAP 3.0 software (Time Series Analysis and Presentation; Rinntech, 2006). 
Thereafter, two reference chronologies were built with 34 increment cores each, sampled from Larix decidua and Picea abies trees growing in undisturbed stands located northeast of the cone. The sites selected for the sampling of reference trees are indicated by asterisks in Figure 2. This step primarily served to compare general growth patterns of undisturbed trees with the tree-ring records of disturbed trees so as to allow distinction of predominant growth conditions (climate, insect outbreaks) from GDs induced by geomorphic processes. The comparison further allowed cross-dating of undisturbed with disturbed tree-ring records and, where applicable, correction of faulty tree-ring sequences derived from disturbed samples (e.g. density fluctuations or missing rings; Cook and Kairiukstis, 1990; Schweingruber, 1996).

\section{Age structure of the stand}

Based on the pith age of the selected trees at breast height, the approximate age structure of the forest stand on the Birchbach cone was assessed. We are aware that tree age at breast height provides neither germination nor inception dates. Nonetheless, it may furnish valuable data on major disturbance events at the cone with reasonable precision, as Larix decidua and Picea abies have been shown to recolonize the surfaces cleared by snow avalanches in the years following an event.

\section{Growth disturbances in trees and their seasonal timing}

Once all disturbed samples had been age corrected, increment curves were investigated so as to assess GDs such as the initiation of abrupt growth reductions, recovery or the onset of compression wood (Shroder, 1980; Braam et al., 1987; Schweingruber, 1996; Fantucci and Sorriso-Valvo, 1999). Further attention was given to the visual analysis of tree rings showing callus tissue overgrowing scars, rows of traumatic resin ducts (TRDs) or reaction wood in tilted conifer stems (Schweingruber, 2001; Stoffel et al., 2005c; Perret et al., 2006). Growth disturbances observed in individual trees were then compiled in a database (Hassler, 2004).

Thereafter, we grouped GDs occurring simultaneously in different trees and defined criteria for the determination of event years. For reasons of limited sample depth (i.e. limited age of trees), strong and abrupt GDs were considered an event year for the period 1750-1850, even if signs were present in only one single tree. In contrast, (i) weak GDs identified in several cores or (ii) an abrupt GD identified in one single tree were disregarded for events occurring after AD 1850, and only the years with several abrupt GDs identified in the samples were kept for further analysis.

After the assessment of event years, we analysed the onset of abrupt changes in cell formation within individual tree rings. Following Stoffel et al. (2005b), analysis was exclusively based on the intra-annual position of callus tissue (i.e. scars) and TRDs, as other types of growth disturbance such as abrupt changes in growth or reaction wood can only be allocated within the growth ring with difficulty, or may even occur in the outer part of the tree ring of the year following an event. Figure 3 shows that TRDs identified at the beginning of the tree ring were attributed to avalanche impacts caused during dormancy (D) or at the very beginning of the growth period of trees in earliest earlywood (EE), i.e. between the end of October and early May. In contrast, TRDs located in late earlywood (LE) or within latewood cell layers (i.e. early [EL], middle $[\mathrm{ML}]$ and late latewood [LL]) were considered the result of

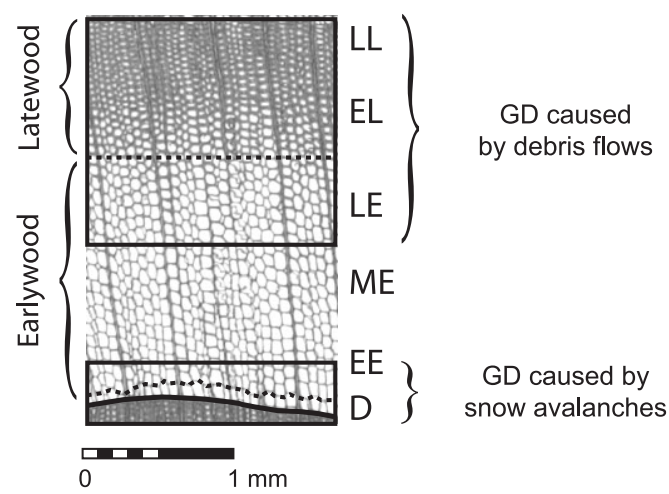

Figure 3. Growth zones within a Larix decidua tree ring and seasonal timing of debris-flow and snow avalanche events at the Birchbach cone. 
debris-flow activity, as these cell layers of the tree ring are locally formed between July and early October. In order to avoid misinterpretation, TRDs located between EE and EL cell layers (i.e. in middle earlywood [ME]) were disregarded.

\section{Spatial distribution of trees disturbed during past debris-flow and snow avalanche events}

In a final analytical step, the spatial distribution of trees showing GDs at identical moments was assessed. This procedure aimed at approximating the (minimum) extent of past snow avalanche events on the cone, or at determining - based on the geomorphic map of the Birchbach cone - whether debris flows used single or multiple channels during particular events. Finally, the spatial analysis of trees showing GD also served to determine the source area (i.e. torrent or avalanche track) of reconstructed debris flows and snow avalanches.

\section{Results}

\section{Geomorphic mapping and identification of forms}

Geomorphic mapping permitted identification of more than 220 deposits related to past debris-flow activity on the Birchbach cone. A large majority of these forms (68\%) were still easily discernible in the field as (small) deposits at the edge of abandoned flow paths or as terminal lobes. In contrast, 106 deposits (34\%) were either partly overgrown with low vegetation or their shape was smoothed by subsequent snow avalanches. In addition, because large parts of the cone are used as extensive pasture land (Bachmann-Voegelin, 1984), the influence of anthropogenic activity on the current appearance of forms and deposits should not be underestimated.

Similarly, geomorphic mapping produced extensive data on abandoned flow paths and levees present on the Birchbach cone. None of these forms could, however, be identified from the apex to the base of the cone, as most of the levees and channels have, again, been largely remodelled by succeeding debris-flow events, snow avalanching or anthropogenic activity. Consequently, the number of abandoned flow paths identified was limited to 18 channels with clearly visible levees over a considerably long distance on the cone.

Debris transport of snow avalanches is, by contrast, mostly limited to uprooted stems, branches or humus, while rocks and boulders are only occasionally deposited on the Birchbach cone. As a consequence, deposits of past snow avalanches were not assessed in greater detail.

\section{Age structure of the stand}

Data on the pith age at breast height indicate that the 251 Larix decidua and Picea abies trees growing on the Birchbach cone are, on average, 105 years old. While the oldest tree selected for analysis attained sampling height in $\mathrm{AD} 1660$, the youngest sample only reached breast height in 1993. As can be seen from Figure 4, the ages of trees as well as their spatial distribution on the cone suggest that parts of the stand must have been eliminated through large snow avalanches, resulting in a relatively homogenous age structure in the trees located northeast of the recently built protection dam or southwest of the current flow path of the Birchbach torrent. According to tree-ring data, seedlings started to recolonize the cone in these two areas in the 1870 s and 1920 s, respectively.

Figure 4 also indicates that the oldest trees can, in contrast, be found near the walking track crossing the cone, where they seem to be reasonably well protected from repeated debris-flow and snow avalanche activity.

\section{Growth disturbances in trees and their seasonal timing}

The 251 Larix decidua and Picea abies trees chosen for analysis permitted identification of 561 growth disturbances (GDs). Most often, rows of traumatic resin ducts (61\%) were identified in the cores, but callus tissue $(7 \%)$, reaction wood $(22 \%)$, abrupt growth releases or growth reductions $(10 \%)$ could be identified as well. By way of example, Figure 5(A) illustrates a short, but abrupt growth reduction occurring as a result of avalanche activity in winter 1998/ 99, whereas Figure 5(B) shows the presence of reaction wood (i.e. compression wood) in the downslope core of a tree tilted in winter $1950 / 51$.

In total, the grouping of GD allowed reconstruction of 30 event years between 1750 and 2002. On average, evidence for individual debris-flow or snow avalanche events is found in five trees, while 27 GDs were reconstructed for a snow avalanche event in 1999. As illustrated in Table II, only one abrupt GD each was used to assess six events dated during the period $1750-1842$. 


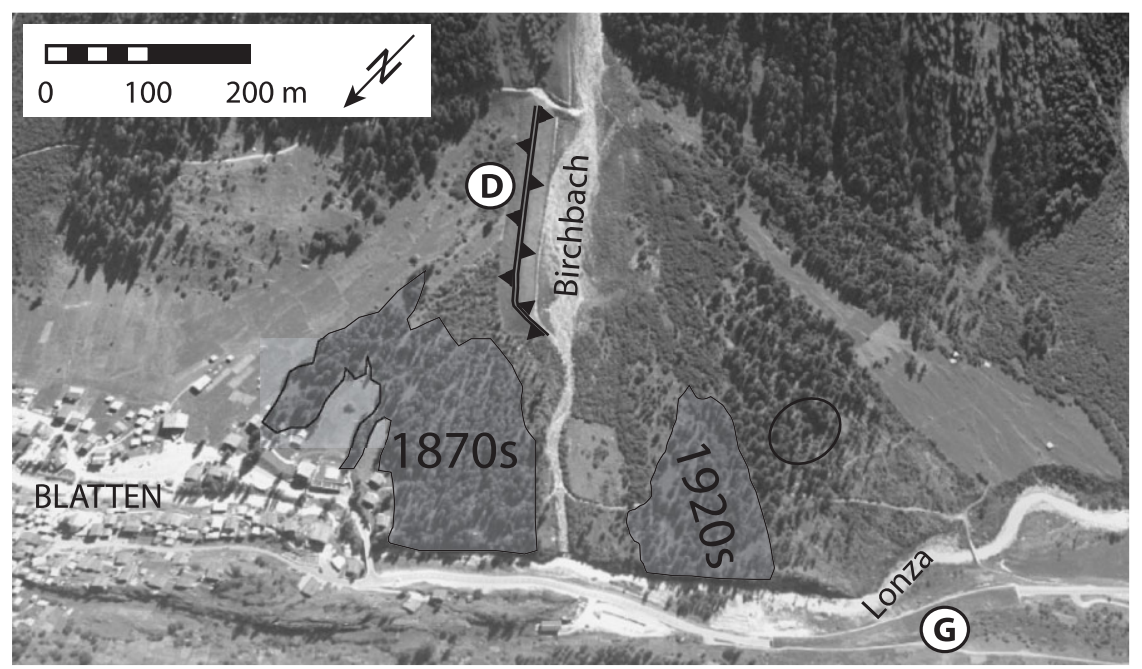

Figure 4. Age structure of stands and recolonization of selected parts of the Birchbach cone after widespread elimination of trees during major snow avalanche events. The circle indicates the area where the oldest trees were identified on the cone.
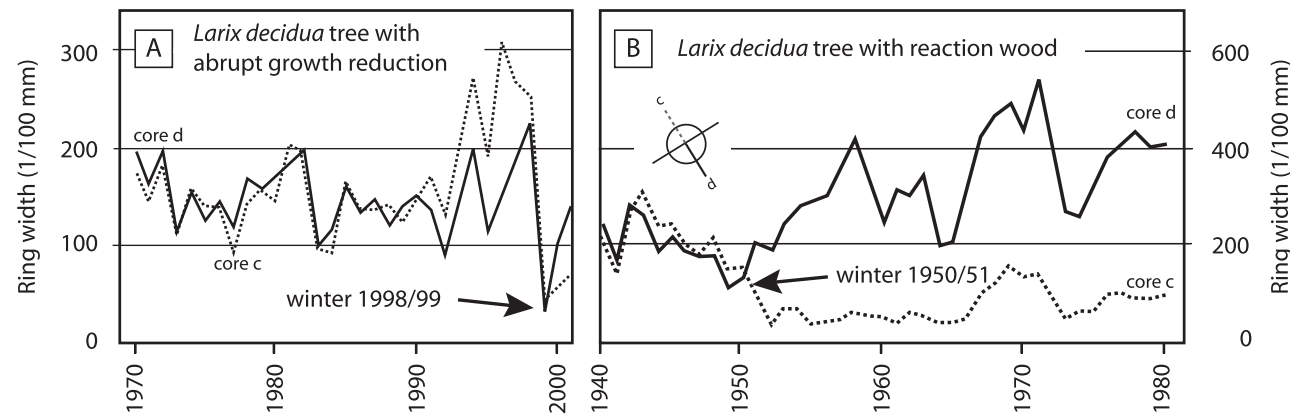

Figure 5. (A) Short, but abrupt growth reduction occurring as a result of damage caused during an avalanche in winter 1998/99; (B) after the tilting of the stem due to an avalanche in winter 1950/5I, this tree started to produce reaction wood on the downslope side of the trunk (core d), whereas increment slightly dropped in core c (raw data: Hassler, 2004).

The seasonal timing of TRDs indicates that nine events (30\%) occurred during the dormant season (D), leaving signs at the very beginning of the succeeding growth period of trees in earliest earlywood (EE). As the dormant season and the succeeding formation of earliest earlywood cell layers occur between the end of October and the beginning of May, we believe that the TRDs associated with these nine event years are the result of past snow avalanche activity.

Table II also illustrates that in 19 event years (63\%), TRDs occurred in late earlywood (LE) or within latewood (L) cell layers, which are locally formed between July and early October (Fischer, 1980). This time of the year coincides with the period of local debris-flow activity.

TRDs were most frequently identified within the last layers of latewood cells $(\mathrm{LL}=30 \%)$, followed by events attributed to the segments of middle $(\mathrm{ML}=17 \%)$ and early latewood $(\mathrm{EL}=13 \%)$ cell layers. In contrast, only one event could be attributed to the period of late earlywood $(\mathrm{LE}=3 \%)$ cell layers.

As illustrated in Table II, a determination of seasonal timing was not possible for two event years (7\%) of the 18th century. Even though the samples clearly show TRDs and callus tissue at the beginning of the tree ring (EE), the signs are considered too weak to designate them as being the result of past snow avalanche activity. Consequently, the event years 1756/57 and 1776/77 are shown with a question mark and given in both the reconstructed debris-flow and snow avalanche frequencies in Figure 6. 
Table II. Illustration of the event years with the number of trees affected and the position of rows of traumatic resin ducts (TRDs) within the tree ring (i.e. seasonality) as well as the process responsible for the damage

\begin{tabular}{|c|c|c|c|}
\hline Year & Trees affected & Seasonality & Process \\
\hline 1998/99 & 27 & $\mathrm{D}$ & Snow avalanche \\
\hline 1992 & 7 & $M L$ & Debris flow \\
\hline 1989 & 3 & $\mathrm{LL}$ & Debris flow \\
\hline $1983 / 84$ & 6 & $\mathrm{D}$ & Snow avalanche \\
\hline 1983 & 6 & $\mathrm{LL}$ & Debris flow \\
\hline $1981 / 82$ & 6 & $\mathrm{D}(\mathrm{EE})$ & Snow avalanche \\
\hline 1979 & 6 & $M L$ & Debris flow \\
\hline 1976/77 & 16 & $\mathrm{D}(\mathrm{EE})$ & Snow avalanche \\
\hline 1970 & 3 & $M L$ & Debris flow \\
\hline 1958 & 6 & LE & Debris flow \\
\hline |950/5 | & 2 & $\mathrm{D}$ & Snow avalanche \\
\hline 1944 & 2 & $\mathrm{LL}$ & Debris flow \\
\hline 1940 & 2 & LL & Debris flow \\
\hline 1928 & 8 & EL & Debris flow \\
\hline 1926/27 & 6 & $\mathrm{D}$ & Snow avalanche \\
\hline $1918 / 19$ & 8 & D & Snow avalanche \\
\hline 1915 & 7 & EL & Debris flow \\
\hline 1898 & 6 & LL & Debris flow \\
\hline 1894 & 4 & LL & Debris flow \\
\hline 1874 & 3 & $M L$ & Debris flow \\
\hline 1855 & 4 & EL & Debris flow \\
\hline 1854/55 & 2 & $\mathrm{D}$ & Snow avalanche \\
\hline 1853 & 4 & LL & Debris flow \\
\hline $1843 / 44$ & 5 & $\mathrm{D}$ & Snow avalanche \\
\hline 1842 & I & EL & Debris flow \\
\hline 1833 & I & $M L$ & Debris flow \\
\hline 1812 & I & $\mathrm{LL}$ & Debris flow \\
\hline 1790 & I & $\mathrm{LL}$ & Debris flow \\
\hline $1776 / 77$ & 1 & $D(?)$ & not clear \\
\hline $1756 / 57$ & 1 & $D(?)$ & not clear \\
\hline
\end{tabular}

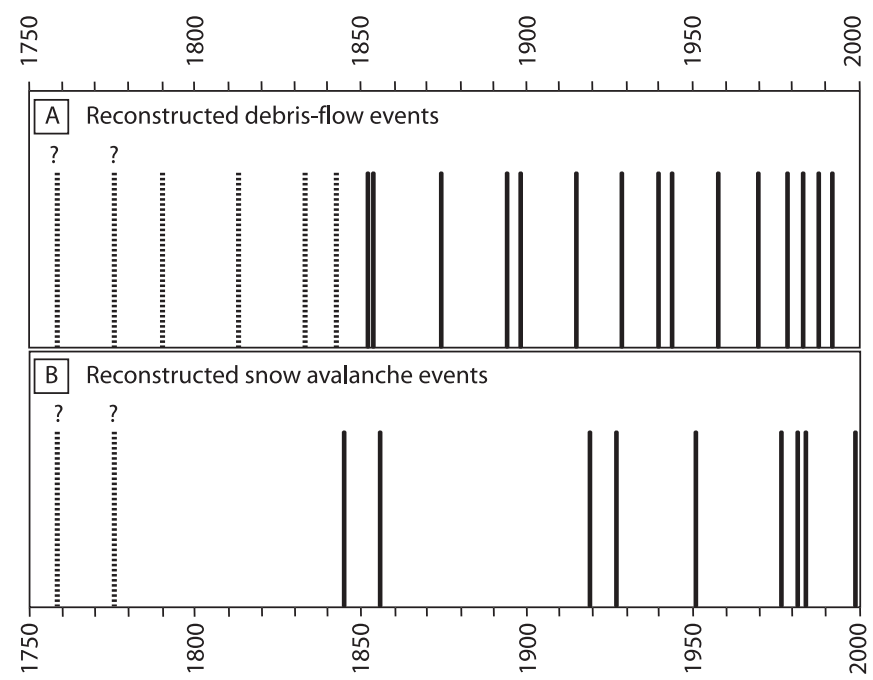

Figure 6. (A) Debris-flow and (B) snow avalanche activity reconstructed from tree-ring records of Larix decidua and Picea abies from the Birchbach cone. Dashed lines indicate past events assessed with a GD in only one tree. For the event years I756/57 and 1776/77, it is not clear whether the growth reactions were caused by debris-flow or snow avalanche activity (raw data: Hassler, 2004). 


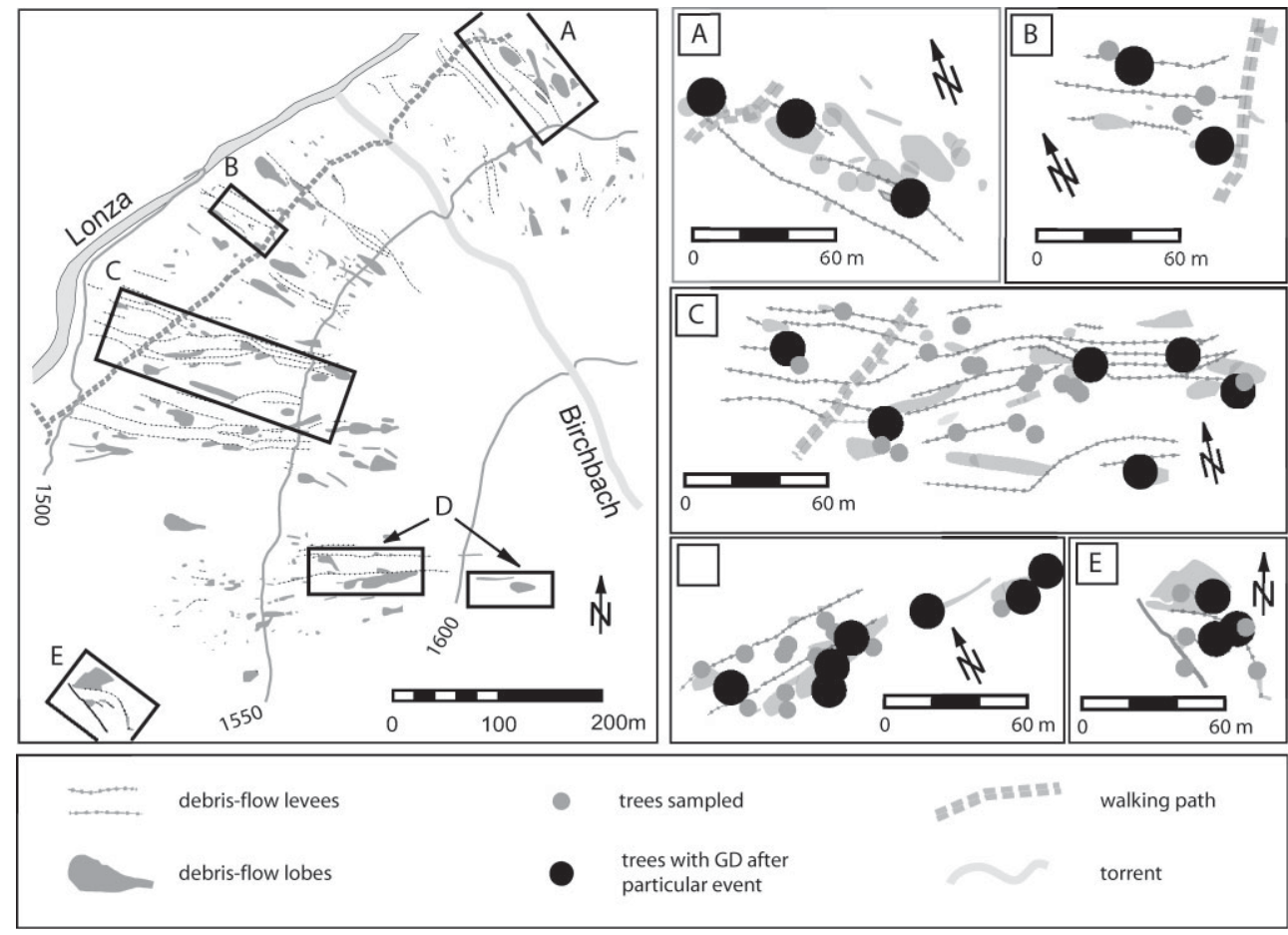

Figure 7. Spatial distribution of trees showing GDs as a result of debris-flow activity (A) east of the current flow path of the Birchbach torrent (1989) and (B) in the central (I944), (C) the north-western (I983) and (D) the south-western (I992) parts of the Birchbach cone. Furthermore, (E) illustrates the position of three trees affected during the 1970 Nästbach debris flow.

\section{Spatial distribution of trees disturbed during past debris-flow events}

The spatial distribution of trees affected simultaneously allowed approximation of the spatial extent and the cone surface influenced by past activity as well as identification of the origin of past debris flows and snow avalanches. Figure 7 illustrates the spatial distribution of characteristic Birchbach debris flows. The distribution of trees affected by debris-flow activity clearly shows that signs are normally restricted to one or a few flow channels. The events reconstructed for 1928, 1915 and 1898 therefore appear to represent abnormal events, as debris-flow material was deposited in various parts of the cone. Surges apparently used or created several flow channels during these events, leaving signs in trees at different locations. Based on our data, we further suppose that debris-flow activity remained quite sparse east of the current flow path of the Birchbach torrent, where GDs can only be detected in 1989 (Figure 7(A)), 1928 and 1898. For the central part of the cone, Figure 7(B) gives the position of trees affected during the 1944 debris flow. In the north-western sector, past debris flows repeatedly caused GDs to the Larix decidua and Picea abies trees chosen for analysis, namely in 1983 (Figure 7(C)), 1979, 1928, 1915, 1898, 1874, 1855, 1853, 1842, 1812 and 1790. Towards the southwestern border of the cone, GDs indicate events in 1992 (Figure 7(D)), 1958, 1940, 1915 and 1833.

Finally, the three GDs reconstructed for the 1970 Nästbach debris flow illustrated in Figure 7(E) clearly show that the channels, lobes and levees identified in the westernmost edge of the cone may be the result of past debris-flow activity in either the Birchbach or Nästbach torrents.

\section{Spatial distribution of past avalanches and identification of source areas}

The spatial analysis of reconstructed GDs attributed to the dormant season (D) and the first cell layers of early earlywood (EE) neatly shows that these reactions would, most frequently, be the result of snow avalanche activity in the 'Birchchinn' gully (see Figure 2). From the nine avalanche events reconstructed on the Birchbach cone, seven would have been triggered from the northwest-facing slopes of the Bietschhorn (3934 m a.s.l.) before passing through the narrow 'Birchchinn' gully, namely in the winters 1983/84, 1981/82, 1976/77 (Figure 8(A)), 1926/27, 1918/19 

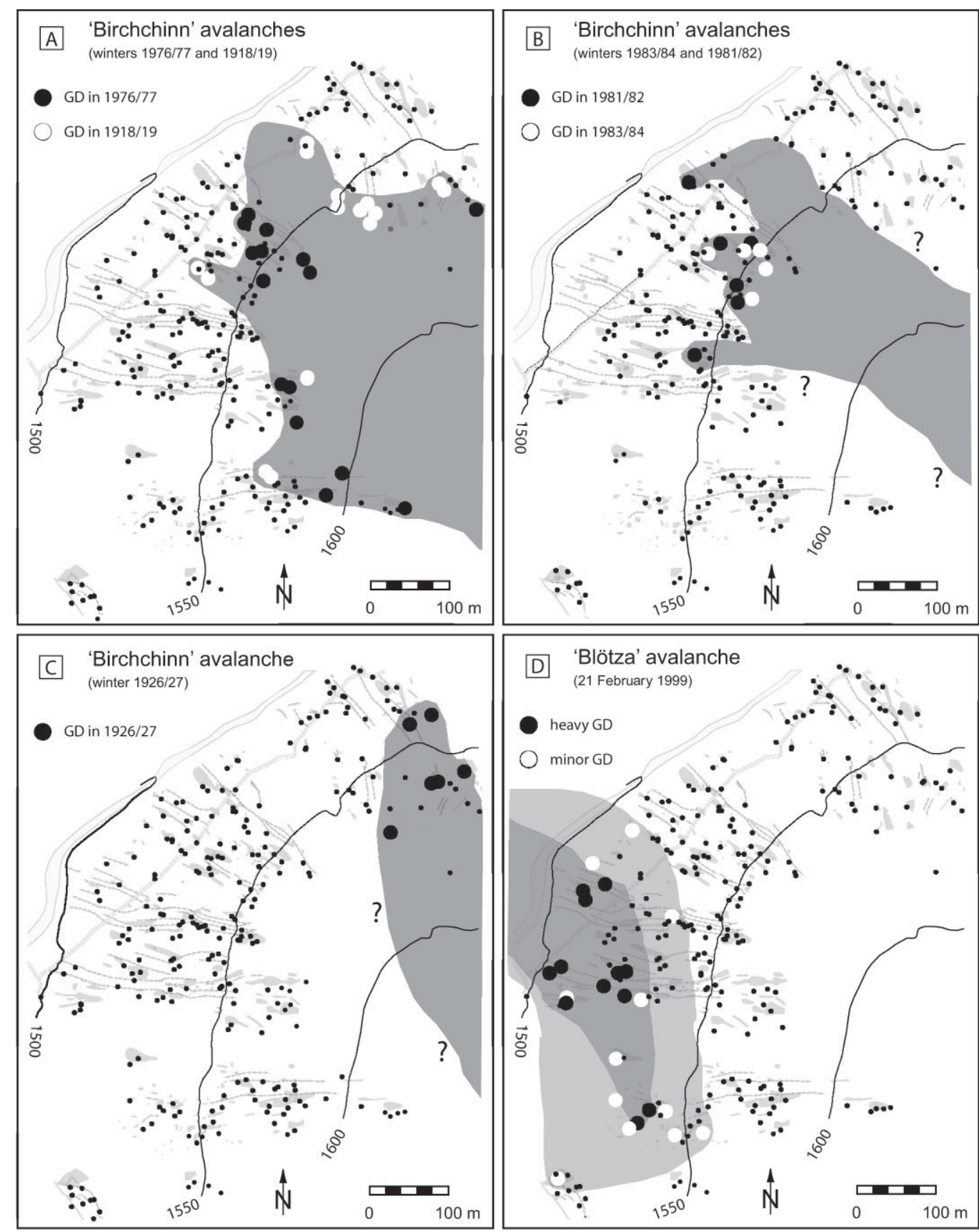

- trees sampled $\quad$ trees with GD during particular event

supposed extent of past snow avalanches

area with GD caused through windblast

Figure 8. Maps showing the distribution of trees disturbed and assumed extent of past 'Birchchinn' avalanches during (A) events affecting large parts of the Birchbach cone in 1976/77 and 19/8/19 and (B) comparably small events restricted to the central sector of the cone in 1983/84 and 1981/82 as well as during (C) an event presumably covering the eastern part of the slope in 1926/27. (D) Trees showing GDs as a consequence of the exceptionally large 'Blötza' powder snow avalanche on 21 February 1999. 
(Figure $8(\mathrm{~A})$ ), $1854 / 55$ and 1843/44. Reconstructed data further show that during these events major parts of the cone would have been covered with avalanche snow and a considerable number of trees affected. In contrast, the snow avalanches reconstructed for the winters 1983/84 and 1981/82, given in Figure 8(B), appear to have been restricted to the central area of the cone, while trees located in the eastern and western parts were apparently not disturbed. Another distribution of disturbed trees is given in Figure 8(C), where a snow avalanche apparently caused GDs to only those trees selected in the eastern part of the slope in winter 1926/27. While it is conceivable that avalanche snow would also have been deposited in the non-forested central part of the slope, dendrogeomorphological analysis indicates a complete absence of GDs in the western parts of the cone.

According to our data, it also appears that past snow avalanches from the nearby 'Nästchinn' gully apparently did not cause GDs in the Larix decidua and Picea abies trees selected on the cone. Nonetheless, and as observed in the winter following the sampling campaign, very large 'Nästchinn' avalanches released from the west-facing slope of the Bietschhorn summit may well disturb or even destroy trees colonizing the Birchbach cone.

Similarly, reconstructed data indicate that very large 'Blötza' avalanches descending from the southeast-facing slopes of the Tennbachhorn (see Figure 1) may cause GDs to the trees on the Birchbach cone as well. Figure 8(D) shows the reconstructed extent of snow masses deposited as well as the area affected by the windblast during the 21 February 1999 avalanche. Contrary to expectation, we found no evidence of former 'Blötza' events in the Larix decidua and Picea abies trees on the Birchbach cone, even though the area of possible deposition of 'Blötza' avalanche snow coincides quite well with the sector containing the oldest trees found on the cone.

Interestingly, and although dendrogeomorphological investigations allowed reconstruction of one out of five known 'Blötza' avalanches in the field, it was not possible to confirm the four snow avalanches (1808-2003) noted in chronicles (Bellwald, 2003) for the 'Birchchinn' gully.

\section{Discussion and Conclusions}

In the study we report here, dendrogeomorphology has been used to assess debris-flow and snow avalanche activity on a forested cone influenced by both processes. For the first time, an assessment of the position of rows of traumatic resin ducts (TRDs) within the tree ring was used to permit attribution of tree damage to either past debris-flow or snow avalanche activity.

Tree-ring analysis of 520 increment cores sampled from 251 strongly disturbed Larix decidua and Picea abies trees allowed identification of 30 event years in the last 252 years (1750-2002). For nine of these event years, the intraseasonal timing of TRDs located within the very first cell layers of the new tree rings - which is locally formed in early May at the latest - clearly showed that signs were the consequence of past snow avalanche activity. Similarly, TRDs occurring in late earlywood or latewood were found in 19 cases, indicating that damage would have been caused between July and early October and, thus, through debris flows in the Birchbach torrent. Interestingly, the seasonal timing of past debris flows as well as the great predominance of TRDs within latewood cell layers widely agree with results obtained at the nearby 'Ritigraben' torrent, where dendrogeomorphological investigations suggest a peak of debris-flow activity in August and September as well (Stoffel et al., 2005a).

Moreover, the complete absence of TRDs identified within middle earlywood (ME) cell layers indicates that neither wet-snow avalanches very late in spring nor exceptionally early debris-flow activity at the beginning of summer occurred on the Birchbach cone during the last 250 years, thus facilitating a certain and unequivocal differentiation of past debris flow from snow avalanche events. As documented by the snow avalanche in winter 1854/55 and a debris flow occurring in summer 1855 (see Figure 6), the methodological approach introduced within this study even allows a distinction of different events occurring within the same tree ring (i.e. 1855).

While the study produced sound results on past debris flows and snow avalanches, it was also restricted by the elimination of parts of the forest stand through large snow avalanches, which led to the rather young age of trees growing on certain sectors of the Birchbach cone, averaging 105 years. Furthermore, it is possible that small debris flows remained within the flow path of the torrent without necessarily causing growth reactions in trees growing on the cone (also see Stoffel et al., 2005a). Likewise, comparably small snow avalanches or events limited to the nonforested parts of the cone cannot be reconstructed with dendrogeomorphological methods. On the other hand, we also need to consider that destructive snow avalanches may not only leave easily recognizable signs (GDs) in tree-ring sequences, but that they may have eliminated large parts of the forest stand at Birchbach and, therefore, blurred evidence of past events as well (Carrara, 1979; Bryant et al., 1989; Schweingruber, 1996). In this sense, there seems to be evidence that tree recolonization in the north-north-western part of the slope during the 1870s (see Figure 4) is the consequence of abundant tree elimination associated with the snow avalanche event in winter 1854/55. Similarly, data clearly indicate that the destructive snow avalanche - reconstructed with tree rings for the winter 1918/19 - 
knocked down the forest stand located in the central part of the cone. As a consequence, trees growing on the cone are much too young to show signs of, e.g., the 1808 'Birchchinn' avalanche event and the reconstructed events may only represent 'minimum frequencies' of past debris-flow and snow avalanche activity.

Similarly, archival data on past snow avalanching in the 'Birchchinn' gully appear to be rather incomplete for the 19th and large parts of the 20th century, containing - most probably - only data on major destructive snow avalanches or spectacular events like the ice avalanche from the Bietschhorn slopes in December 1993. On the other hand, abundant avalanche activity with many destructive events in late February 1999 apparently led to increased avalanche awareness, giving even small and non-destructive snow avalanches access to the database in the years 2000 to 2003 (Bellwald, 2003).

Moreover, matches between archival information and reconstructed snow avalanches can be improved considerably if avalanching in other gullies within the Lötschental valley is taken into account as well: we are thus able to identify analogues for our reconstructed 'Birchchinn' avalanches in 1983/84, 1981/82, 1926/27 or 1918/19.

Interestingly, the huge 'Blötza' powder snow avalanche in 1999 apparently represents the only event from the northeast-facing slope that would have crossed the Lonza river and reached the cone on the opposite valley slope. Even though we have to admit that the 1999 avalanche has - probably - to be seen as one of the major events for this avalanche track, we nonetheless suppose that the recent construction of the road gallery illustrated in Figure 2 would have made it much easier for snow masses to pass over the Lonza river and, as a consequence, to cause damage to trees on the Birchbach cone.

We conclude that the approach outlined in this study proved to be a useful tool for analysing past debris flows and snow avalanches on forested cones affected by both processes. The results presented also show that dendrogeomorphological analysis of TRDs clearly has the potential to allow distinction of past debris-flow from snow avalanche events. Nonetheless, replicate studies are needed to further refine the methods used within this study or to focus on wood-anatomical changes occurring with these events in greater detail. Lastly, future studies should try to identify anatomical differences related to geomorphic processes, so as to allow differentiation of events that might occur simultaneously, such as rockfall and snow avalanches (Jomelli and Francou, 2000).

\section{Acknowledgements}

The authors are grateful to Dr. Holger W. Gärtner (Swiss Federal Research Institute WSL) for all manner of assistance in the field and the laboratury. We thank Dr. Burkhard Neuwirth and the other members of the Tree-Ring Laboratury of the Friedrich-Wilhelms University of Bonn for the introductory fieldtrip. Professor Michel Monbaron's financial and moral support is also gratefully acknowledged. While Dominique Schneuwly made helpful comments on an earlier version of the paper, Heather Murray improved the English. Lastly, we want to express our gratitude to Brian H. Luckman and an anonymous reviewer for their careful reviewing.

\section{References}

Ackroyd P. 1986. Debris transport by avalanche, Torlesse Range, New Zealand. Zeitschrift für Geomorphologie N.F. 30: 1-14.

André MF. 1990. Geomorphic impact of spring avalanches in Northwest Spitsbergen. Permafrost and Periglacial Processes 1: 97-110.

Bachmann-Voegelin F. 1984. Blatten im Lötschental - die traditionelle Kulturlandschaft einer Berggemeinde. Haupt: Bern.

Baumann F, Kaiser KF. 1999. The Multetta debris fan, eastern Swiss Alps: a 500-year debris flow chronology. Arctic and Alpine Research 31(2): 128-134.

Bell I, Gardner J, DeScally F. 1990. An estimate of snow avalanche debris transport, Kaghan valley, Himalaya, Pakistan. Arctic and Alpine Research 22: 317-321.

Bellwald M. 2003. Lötschentaler Lawinenchronik. Schnee- und Lawinenbeobachtungen 1680-2003. Eigenverlag: Wiler.

Bollschweiler M, Stoffel M, Schneuwly D. 2005. Veränderungen der Murrinnen im Täschgufer seit 1936. Wasser Energie Luft 97(7/8): 218223.

Bovis MJ, Jakob M. 1999. The role of debris supply conditions in predicting debris flow activity. Earth Surface Processes and Landforms 24(11): 1039-1054.

Braam RR, Weiss EEJ, Burrough PA. 1987. Spatial and temporal analysis of mass movement using dendrochronology. Catena 14: $573-584$.

Bryant CL, Butler DR, Vitek JD. 1989. A statistical analysis of tree-ring dating in conjunction with snow avalanches: comparison of on-path versus off-path responses. Environmental Geology and Water Sciences 14(1): 53-59.

Butler DR, Malanson GP, Walsh SJ. 1992. Snow-avalanche paths: conduits from the periglacial-alpine to the subalpine-depositional zone. In Periglacial Geomorphology, Dixon JC, Abrahams AD (eds). Wiley: Chichester; 185-202.

Caine N. 1980. The rainfall intensity-duration control of shallow landslides and debris flows. Geografiska Annaler 62A: 23-27.

Cannon SH, Gartner JE, Parrett C, Parise M. 2003. Wildfire-related debris-flow generation through episodic progressive sediment bulking processes, western USA. In Debris-Flow Hazards Mitigation: Mechanisms, Prediction, and Assessment, Rickenmann D, Chen CL (eds). Millpress: Rotterdam; 71-82. 
Carrara E. 1979. The determination of snow avalanche frequency through tree-ring analysis and historical records at Ophir, Colorado. Geological Society of America Bulletin 90: 773-780.

Cook ER, Kairiukstis LA. 1990. Methods of Dendrochronology - Applications in the Environmental Sciences. Kluwer: London.

Costa JE. 1984. Physical geomorphology of debris flows. In Developments and Applications of Geomorphology, Costa JE, Fleisher PJ (eds). Springer: Berlin; 268-317.

Costa JE. 1988. Rheologic, geomorphic, and sedimentologic differentiation of water floods, hyperconcentrated flows, and debris flows. In Flood Geomorphology, Baker VR, Kochel RC, Patton PC (eds). Wiley: London; 113-122.

Fantucci R, Sorriso-Valvo M. 1999. Dendrogeomorphological analysis of a slope near Lago, Calabria (Italy). Geomorphology 30: $165-174$.

Fischer F. 1980. Verjüngungszustand und Jungwaldaufbau im Gebirgswald - einige Beispiele aus dem Lötschental. Beihefte zu den Zeitschriften des Schweizerischen Forstvereins 67: 1-57.

Gardner J. 1970. Geomorphic significance of avalanches in the Lake Louise District. Arctic and Alpine Research 2: $135-144$.

Guntern J. 1978. Volkserzählungen aus dem Oberwallis - Sagen, Legenden, Märchen, Anekdoten aus dem deutschsprechenden Wallis. Krebs: Basel.

Hassler GR. 2004. Dendrogeomorphologische Untersuchungen am Birchbachkegel (Lötschental, Schweiz). Unpublished diploma thesis, Department of Geosciences, Geography, University of Fribourg: Fribourg.

Hebertson EG, Jenkins MJ. 2003. Historic climate factors associated with major avalanche years on the Wasatch Plateau, Utah. Cold Regions Science and Technology 37: 315-332.

Helsen MM, Koop PJM, van Steijn H. 2002. Magnitude-frequency relationship for debris flows on the fan of the Chalance torrent, Valgaudemar (French Alps). Earth Surface Processes and Landforms 27: 1299-1307.

Hubert TP. 1982. The geomorphology of subalpine snow avalanche runout-zones: San Juan Mountains, Colorado. Earth Surface Processes and Landforms 7: 109-116.

Huggel C, Kääb A, Haeberli W, Teysseire P, Paul F. 2002. Remote sensing based assessment of hazards from glacier lake outbursts: a case study in the Swiss Alps. Canadian Geotechnical Journal 39: 316-330.

Hungr O, Morgan GC, Kellerhals R. 1984. Quantitative analysis of debris torrent hazard for design of remedial measures. Canadian Geotechnical Journal 21(4): 663-677.

Imhof M. 1996. PERM - ein Programm für die automatisierte Kartierung von Permafrost in den Schweizer Alpen. In Simulation der Permafrostverbreitung in den Alpen mit geographischen Informationssystemen, Haeberli W, Hölzle M, Dousse JP, Ehrler C, Gardaz JM, Imhof M, Keller F, Kunz P, Lugon R, Reynard E (eds). vdf Hochschulverlag: Zürich; 25-33.

Innes JL. 1985. Lichenometric dating of debris-flow deposits on alpine colluvial fans in southwest Norway. Earth Surface Processes and Landforms 10: 519-524.

Jakob M, Bovis M, Oden M. 2005. The significance of channel recharge rates for estimating debris-flow magnitude and frequency. Earth Surface Processes and Landforms 30: 755-766.

Johnson AM. 2003. Use of Claude Bernard's scientific method to understand debris flow. Keynote lecture. In Debris-Flow Hazards Mitigation: Mechanisms, Prediction, and Assessment, Rickenmann D, Chen CL (eds). Millpress: Rotterdam; 3-21.

Johnson AM, Rodine JR. 1984. Debris flow. In Slope Instability, Brundsen D, Prior DB (eds). Wiley: New York; $257-361$.

Johnson EA, Hogg L, Carlson CW. 1985. Snow avalanche frequency and velocity for the Kananaskis Valley in the Canadian Rockies. Cold Regions Science and Technology 10: 141-151.

Jomelli V. 1999. Caractéristiques morphosédimentaires des depots d'avalanches en haute montagne alpine; variations spatio-temporelles de leur mise en place depuis le Petit Age Glaciaire. Géographie Physique et Quaternaire 53(2): 199-209.

Jomelli V, Francou B. 2000. Comparing the characteristics of rockfall talus and snow avalanche landforms in an Alpine environment using a new methodological approach: Massif des Ecrins, French Alps. Geomorphology 35: 181-192.

Jonasson C, Kot M, Kotarba A. 1991. Lichenometrical studies and dating of past debris flow deposits in the High Tatra Mountains, Poland. Geografiska Annaler 73A: 141-146.

Jossen P. 1994. Blatten - zwischen Bietschhorn und Petersgrat. Rotten: Brig.

Krusic PM, Kenney M, Hornbeck J. 1987. Preparing increment cores for ring-width measurements. Northern Journal of Applied Forestry 4: $104-105$.

Labhart TP. 2004. Geologie der Schweiz (6th edn). Ott: Thun.

Luckman BH. 1977. The geomorphic activity of snow avalanches. Geografiska Annaler 59A: 31-48.

Luckman BH. 1978. Geomorphic work of snow avalanches in the Canadian Rocky mountains. Arctic and Alpine Research 10: $261-276$.

Luckman BH. 1992. Debris flow and snow avalanche landforms in the Lairig Ghru Cairngorm mountains, Scotland. Geografiska Annaler 74A: 109-121.

Matthews JA, McCarroll D. 1994. Snow-avalanche impact landforms in Breheimen, southern Norway: origin, age, and paleoclimatic implications. Arctic and Alpine Research 26(2): 103-115.

May CL, Gresswell RE. 2004. Spatial and temporal patterns of debris-flow deposition in the Oregon Coast Range, USA. Geomorphology 57(3/4): 135-149.

McCarroll D. 1993. Modelling late-Holocene snow-avalanche activity: incorporating a new approach to lichenometry. Earth Surface Processes and Landforms 18: 527-539.

Patten RS, Knight DH. 1994. Snow avalanches and vegetation pattern in cascade canyon, Grand Teton National Park, Wyoming, USA. Arctic and Alpine Research 26(1): 35-41.

Perret S, Stoffel M, Kienholz H. 2006. Spatial and temporal rockfall activity in a forest stand in the Swiss Prealps - a dendrogeomorphological case study. Geomorphology 74: 219-231. 
Phipps RL. 1985. Collecting, Preparing, Crossdating, and Measuring Tree Increment Cores, US Geological Survey Water Resources Investigations Report 85-4148.

Rapp A. 1960. Recent development of mountain slopes in Kärkevagge and surroundings, Northern Scandinavia. Geografiska Annaler 42: 65-200.

Rapp A, Nyberg R. 1981. Alpine debris flows in northern Scandinavia. Geografiska Annaler 63A: 183-196.

Rayback SA. 1998. A dendrogeomorphological analysis of snow avalanches in the Colorado Front Range, USA. Physical Geography 19(6): $502-515$.

Rickenmann D. 1999. Empirical relationships for debris flows. Natural Hazards 19: 47-77.

Rinntech. 2006. http://www.rinntech.com/Products/Lintab.htm

Schweingruber FH. 1996. Tree Rings and Environment. Dendroecology. Haupt: Bern.

Schweingruber FH. 2001. Dendroökologische Holzanatomie. Haupt: Bern.

Schweingruber FH, Eckstein D, Serre-Bachet F, Bräker OU. 1990. Identification, presentation and interpretation of event years and pointer years in dendrochronology. Dendrochronologia 8: 9-39.

Shroder JF. 1980. Dendrogeomorphology: review and new techniques of tree-ring dating. Progress in Physical Geography 4: $161-188$.

SLF (Eidgenössisches Institut für Schnee- und Lawinenforschung). 2000. Der Lawinenwinter 1999. Ereignisanalyse. Eidgenössisches Institut für Schnee- und Lawinenforschung: Davos.

Smith DJ, McCarthy DP, Luckman BH. 1994. Snow-avalanche impact pools in the Canadian Rocky Mountains. Arctic and Alpine Research 26(2): 116-127.

Smith MJ, McClung DM. 1997. Characteristics and prediction of high-frequency avalanche runout. Arctic and Alpine Research 29(3): 352357.

Stoffel M, Gärtner H, Lièvre I, Monbaron M. 2003. Comparison of reconstructed debris-flow event years (Ritigraben, Switzerland) and existing flooding data in neighboring rivers. In Debris-Flow Hazards Mitigation: Mechanisms, Prediction, and Assessment, Rickenmann D, Chen CL (eds). Millpress: Rotterdam; 243-253.

Stoffel M, Lièvre I, Conus D, Grichting MA, Raetzo H, Gärtner HW, Monbaron M. 2005a. 400 years of debris flow activity and triggering weather conditions: Ritigraben VS, Switzerland. Arctic, Antarctic and Alpine Research 37(3): 387-395.

Stoffel M, Lièvre I, Monbaron M, Perret S. 2005b. Seasonal timing of rockfall activity on a forested slope at Täschgufer (Valais, Swiss Alps) - a dendrochronological approach. Zeitschrift für Geomorphologie 49(1): 89-106.

Stoffel M, Schneuwly D, Bollschweiler M, Lièvre I, Delaloye R, Myint M, Monbaron M. 2005c. Analyzing rockfall activity (1600-2002) in a protection forest - a case study using dendrogeomorphology. Geomorphology 68(3/4): 224-241.

Strunk H. 1995. Dendrochronologische Methoden zur Ermittlung der Murfrequenz und Beispiele ihrer Anwendung. Roderer: Regensburg.

Strunk H. 1997. Dating of geomorphological processes using dendrogeomorphological methods. Catena 31: $137-151$.

Takahashi T. 1991. Debris flows, IAHR Monograph Series. Balkema: Rotterdam.

Ward RGV. 1985. Geomorphological evidence of avalanche activity in Scotland. Geografiska Annaler 67A: 247-256.

Zimmermann M, Mani P, Romang H. 1997. Magnitude-frequency aspects of alpine debris flows. Ecologae Geologicae Helvetiae 90(3): $415-420$. 